\title{
The book on how to make all the colour paints for illuminating books: unravelling a Portuguese Hebrew illuminators' manual
}

\author{
Maria J. Melo ${ }^{1 *} \mathbb{B}$, Rita Castro ${ }^{1}$, Paula Nabais ${ }^{1}$ and Tatiana Vitorino ${ }^{1,2}$
}

\begin{abstract}
The book on how to make all the colour paints for illuminating books invites readers to step inside the workshop of a fifteenth century illuminator in Portugal. This illuminator was the carrier of a tradition on how to make colours with 'which you can illuminate or paint or capitalize or write' that dates back, at least, to the thirteenth century. This unique knowledge and know-how was carefully preserved in Portuguese language, in Hebrew characters, in a collection of texts now known as Ms. Parma 1959 (Parma, Italy, Biblioteca Palatina, MS 1959, folios 1r-20r). Its ultimate purpose was possibly to assist on the production of Hebrew Bibles, where the precision of the text would have been illuminated by the colours described in this 'book of all colour paints'. This medieval treatise describes the main steps and ingredients for producing painting materials, such as mosaic gold, red lead, verdigris, brazilwood lake pigments, lac dye red, vermilion, parchment glue, among others. It also instructs on the binding media that should be used to produce the colour paints. In this paper, we will discuss the technical aspects relevant for the success of the making of the painting materials and of the experimentation of this remarkable text, copied in the fifteenth century.
\end{abstract}

Keywords: Medieval, Pigments, Paints, Illuminations, Treatise, Recipe, Portuguese Hebrew

\section{Introduction}

We have been studying and reconstructing the medieval processes to make pigments and paints which were used to create medieval manuscript illuminations with the long-term goal of conserving them in the original artworks [1-3]. The establishment of a dialogue between the medieval written sources and the multi-analytical molecular characterisation of the original colours has been our primary approach. This research has been carried out within an interdisciplinary team which includes conservators, chemists, and art historians.

The rationalisation of the processes to make medieval pigments and paints are made through the chemical knowledge of the twenty first century. The reproduction is carried out with as much historical accuracy as possible, taking advantage of the shortcuts offered by today's

\footnotetext{
*Correspondence: mjm@fct.unl.pt

1 Department of Conservation and Restoration and LAQV-REQUIMTE,

Faculty of Sciences and Technology, NOVA University of Lisbon,

2829-516 Caparica, Portugal

Full list of author information is available at the end of the article
}

chemistry, and validated as a reference through comparison with the molecular characterisation of the original colours found in the illuminations [4-7]. The success of the validation depends on the depth of the molecular characterisation since the paints found in medieval illuminations are heterogeneous formulations which include pigments, binders, additives and varnishes. If from a molecular point of view, including morphology, the reproduced colour paint matches the original, it is considered a reconstruction and it is integrated in a database. These reconstructions become reference material to test new approaches for analytical characterisation, to study degradation mechanisms, and, finally, to test innovative methods to conserve the medieval illuminations.

The processes to make pigments and paints presented in the oldest Portuguese text on the colours of medieval illumination have been reconstructed and the knowledge obtained is presented as Additional file 1 [8]. In this paper, we will discuss technical aspects relevant for the experimentation of this remarkable scientific text, copied in the fifteenth century. 


\section{The book on how to make all the colour paints for illuminating books}

The text in the 'book on how to make all the colour paints for illuminating books' dates back at least to the thirteenth century and tells us about the science and art of making and applying colours with 'which you can illuminate or paint or capitalize or write. Débora Marques de Matos, based on convincing evidence, proposes that it was possibly copied by Abraham ibn Hayyim in 1462; the scribe was not the author of the text [9]. This thirteenth to fifteenth century medieval treatise describes the main steps and ingredients for producing colourants, such as mosaic gold, red lead, verdigris, brazilwood, lac dye, vermilion, among others; it instructs also on how to temper and produce colour paints. This knowledge was carefully preserved in Portuguese language written in Hebrew characters, in a collection of texts, now known as Ms. Parma 1959. The original manuscript, MS 1959, folios 1r-20r, is kept in Biblioteca Palatina, Parma (Italy). Its ultimate purpose was to possibly assist on the production of Hebrew Bibles, where the precision of the text would have been illuminated by the colours described in this 'book of all colour paints'. The treatise was recently studied by an interdisciplinary team of researchers led by Luís U. Afonso and Victor Serrão in the project 'As Matérias da Imagem' [10, 11]. Other scholars have also made major contributions for our knowledge on this precious text, and include the first edition, with English translation, by Blondheim (1928), the Portuguese translation by Moreira de Sá (1960) and, recently, the English translation and transliteration by Devon Strolovich [12-14]. Inès Villela-Petit also stood out as one of the first researchers to question Blondheim's dating of the Ms. Parma 1959 [15]. More recently, another edition was published by Larroche [16].

\section{Experimenting with the 'book of all colour paints'}

The most recent edition of the treatise by Strolovitch [14] helped us understand more clearly the processes' description as well as the comments needed for the success of the colours' reproduction. Although the steps for the recipes are precise and clearly described, the fact that we have centuries separating us from the medieval practice and the daily routine of medieval illuminators may obliterate some processes that were common practice and obvious at that time, but unclear to us presently. When the results of the reproduction were disappointing, we tried to reinterpret the science and technology of the process. Each reproduction and each different approach, and more than 10 years of experimentation have allowed us to reconstruct the materials used in the past to create medieval illuminations. Systematic comparison with medieval illuminations in Portuguese collections has served as a two-fold support, either by validating the results obtained which can then be used as reference materials for future research, or by providing insight into the processes to which we should pay a greater amount of attention and the way in which they should be reproduced.

In the Additional file 1, the experimental edition of the 'book of all colour paints' is presented, as individual chapters, each one corresponding to a process for making colour, and focuses on the organic- and inorganic-based colours. Each chapter includes the English translation of the process, the description of the reproduction carried out in the laboratory, and the rationalisation and chemical reactions involved. Key aspects of the processes, missing/obscure indications, as well as comments are also presented. The chapters are further completed with the identification of the respective colour paint in Portuguese medieval illuminations, the references cited and sources for further reading, and an appendix with the colour, molecular and elemental characterisation of the pigment and paint reproduced. Some of the processes are still work in progress since some steps remain to be understood, while other are to be kept in permanent update.

\section{All colour paints}

There are eleven colour names listed in the book of all colour paints' (Table 1). The processes for making these colours, based on both organic and inorganic pigments, are presented for only nine, the majority of which have been reproduced and are presented in the online technical commentary. These include mosaic gold, silver blue, brazilwood, red lead, verdigris, lac, vermilion, katasol (turnsole), and green lake. In the following sections, we present the colours which have been extensively reproduced and found in medieval illumination in Portuguese collections, as well as those which still represent a challenge to reproduce.

\section{The green and blue colours}

It is interesting to note that, in principle, for each colour there is a process that leads to an inorganic pigment and another to an organic dye; this is the case for blue, yellow, red and green.

For the inorganic green, two recipes are proposed that produce a neutral copper acetate, although for the time being with rather low yields. The low yields result from the low concentration (chap 11) or absence (chap 12) of acetic acid in the gas phase. Nevertheless, the suggestion of using warm vinegar is striking as we concluded that, indeed, this is an important procedure for increasing the reaction yields. 
Table 1 The ten colours described in chapter 27; 'the principal colours are ten: blue, orpiment, and vermilion, green, sufi carmine, katasol (turnsole), saffron, red lead, white lead, brazilwood'

\begin{tabular}{|c|c|c|c|c|c|c|c|c|c|c|}
\hline Azul & Orpimento & Vemelyon & Verde & Karmen & Çuf'y & Katasol & Açafrao & $A z^{a}$ rkon & $\begin{array}{c}\text { Alvay }^{a} \\
\text { Ide }\end{array}$ & Brasil \\
\hline 5 & - & 15 & $\begin{array}{c}11,12 \\
45\end{array}$ & 13,14 & - & 24 & 36 & 10 & - & $\begin{array}{c}8,9,27 \\
44\end{array}$ \\
\hline
\end{tabular}

Last row: chapters where the making off is described

The organic green obtained from Iris germanica is based on the capture of an anthocyanin supramolecular complex $[17,18]$, which together with yellow flavones also present in the plant petals, will produce a green colour. This is a work in progress as only recently we have planted the flower to ensure the accurate usage of fresh material.

The organic blue, possibly turnsole, will be addressed in "The incomplete recipe of katasol".

Unfortunately, we were not yet able to obtain silver blue from 'leaves of sterling Luna, that is, very thin leaves of sterline silver'. The 'sterline silver' used to prepare the 'fine blue' (nobre azul) had possibly a different composition from what is presently used for sterling silver. We are confident that once this relevant detail has been elucidated we will be able to reproduce this pigment.

\section{The roses of brazilwood}

Brazilwood was an important source for pink and red colours in medieval times. Although it is, currently, considered less stable to light than the anthraquinone reds (carminic acid, laccaic acid, alizarin, and purpurin), the processes to produce brazilwood colours appear in a higher number in the 'book of all colour paints' than the other colours. Our studies in medieval illuminations have shown that this pigment was extensively used and it is a stable colour in the medieval codex, being found under four tonalities: a translucent carmine, an opaque dark rose, a light and lively opaque rose, and a faded opaque rose (Fig. 1). The 'book on how to make colours' contains processes for producing different rose colours from brazilwood in chapters 8, 9, 27 and 44 (Table 1). For rationalisation of the processes, several experiments were carried out in the laboratory. In the end, the four processes are for preparing either a dark red or a rose colour. The latter is characterised by a higher $L^{*}$ value and a component in the yellow $\left(b^{*}>0\right)$ or blue $\left(b^{*}<0\right)$ together with a red component $\left(\mathrm{a}^{*}>0\right)$ and is obtained with the processes described in chapters 8 and 27 in which the colour from the natural wood source is extracted with urine. Depending on the quantity of extender added, calcium carbonate, basic lead carbonate, or calcium sulphate dihydrate (gypsum), more opaque will be the resulting pigment. The processes presented in chapters 9 and 44, on the other hand, refer an extraction with lye and lime, which result in a dark red colour. Alum is present in all four processes, as a source of aluminium ions that complex with the chromophore of brazilwood. Chapter 8 also calls for the dye solution to be filtered over a chalk or gypsum stone (the actual term in the recipe is 'piah feitah de gis o de pedra kri, 'trough made of gypsum or chalk stone'). In contrast, the other recipes do not mention the filtration step. It is unclear whether this represents an omission because filtration was assumed, or whether it means that no filtration was done in the latter recipes. For example, in chapter 44, instructions say to grind and then sift the brazilwood. Sifting could result in the larger wood scrapings being removed leaving only the smallest particles, making filtration unnecessary (however, in our reproductions some small brazilwood scrapings are present in the final pigment).

\section{The sulfured-colours, mosaic gold and vermilion}

Two of the most interesting recipes on the 'book of all colour paints' are the recipes for mosaic gold (Fig. 2) and vermilion, both sulphide based pigments. For the first we have, as for many other colours, two different processes; for vermilion, only one recipe. For both pigments, we found a detailed list of materials and equipment as well as precise instructions for the heating process; we are also given exceptional details such as (i) the use of a 'dog's foot' for bringing together mercury and sulphur to produce black HgS: it is advised to 'always stirring it with a dog's foot that has its hair and wool, which allows to capture the much fugacious mercury. Those who have not worked with the 'fugitive'-one of the many names for mercury-cannot imagine the advantage of this information; (ii) And the use of a glass vessel to produce mosaic 
the middle vein right through the folinge, wich is painted light red, and with middle vern right through the green or slate green, as it is shown here.

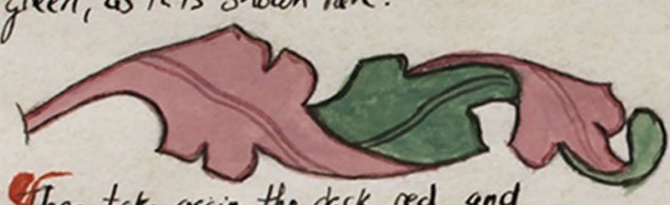

Then take again the dark red and mit it thinner in the hand or in a shell with pure, thin gum water, so that it is really thimner, as shown here: Then take the same thin dark red for one side, ramely the tumaver of the leaf, or of the reverse, as it is shown here. Then take dark green and mix. it thinner with pure spring water in the hand, or in whatever you wish, so that thon it is really thinner, as it is shown here: paint in the green with a brush, as it is shown here.

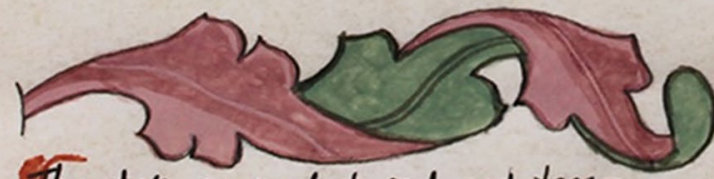

Then take agrin clark red and temper it with gum water, not too strong and also not too thin, that is to say an ink, wichis ant too thin, so that it flows casily from the bead. whath his you shade' the lisht red namely with the watery red, with little strokes, as it is shoun here. Then take dark creen and temper. it with pure weter, but do not stir it with the finger, but let the feuid dissolve by itself, that it gets as thick as thin ink. With it you shade the green, namely with the watery dark green, the same way as the red, and as it is showin here.

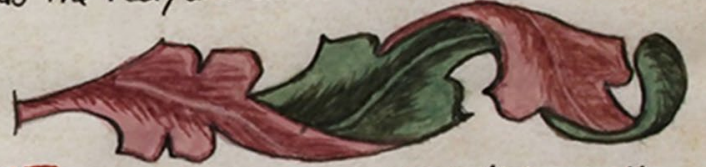

Then take lead white, wich shall be well ground, and with it heighten the light red with a grush on the shadel port of the lect or the fuliage, and so, that the litile strokes of white are smaller, as is shown here. Then take on the midble vein, wich shall be a double line, with a brush and the lad white little dots, as it is shown here.

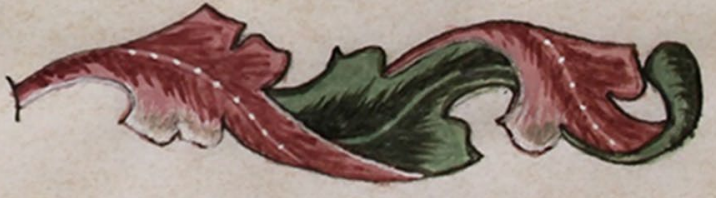

Fig. 1 Example of a reproduction of the Göttingen Model Book prepared by students from the master's degree program in Conservation and Restoration; the rose colours are painted with a brazilwood pigment reconstruction
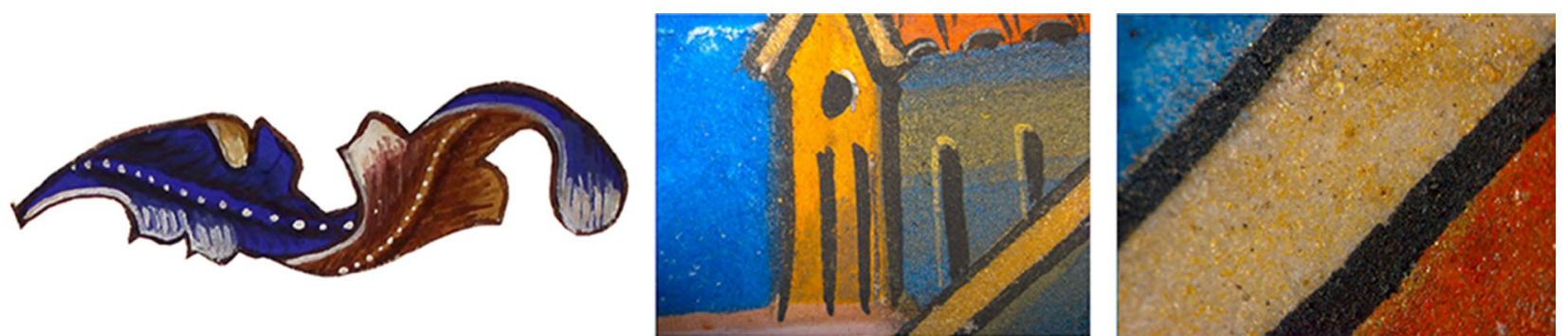

Fig. 2 From left to right. Example of a reproduction of the Göttingen Model Book prepared by students from the master's degree program in Conservation and Restoration; the yellow colour is painted with a mosaic gold pigment reconstruction. Mosaic gold applied on the Ajuda Songbook, fol. 17 and fol. 40v

gold [19]; the precise importance and function of this glass vessel, a costly material in medieval times, is still being investigated.

\section{The incomplete recipe of katasol}

Katasol refers possibly to turnsole, ${ }^{1}$ which Mark Clarke, in his critical edition of technical middle English

${ }^{1}$ D. Strolovitch translates it as "sunflower juices", but this cannot be correct and does not make sense as it is not possible to obtain a blue/purple colour from sunflowers. 

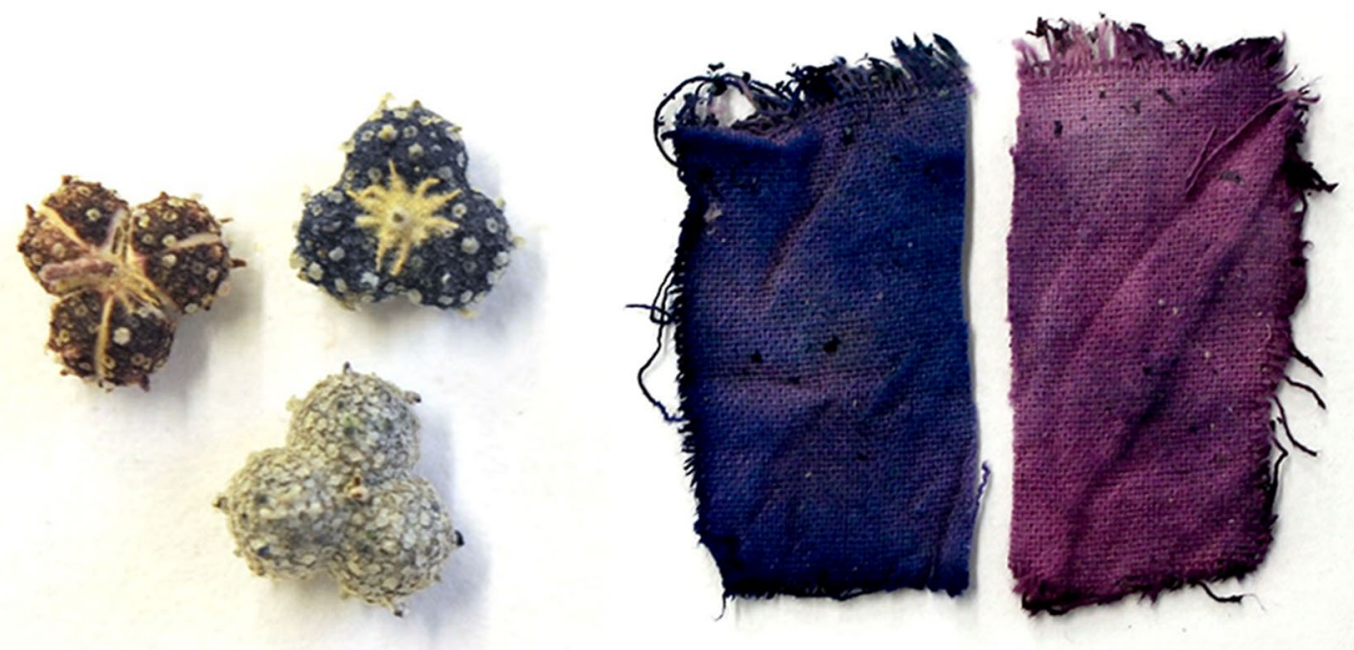

Fig. 3 Chrozophora tinctoria, close-up of the fruits, and dyed cloth with the juice of the fruits according to the recipe of the 'book of all colour paints'; blue after exposition to vapours of urine and purple after exposed to sunlight. Fruits were collected in August and September 2017, near Granja-Amareleja, Alentejo, Portugal

treatises, refers to as being a generic nomination for a cloth used to capture a certain colour, often, but not necessarily, Chrozophora tinctoria [20]. ${ }^{2}$ We propose that in the 'book of all colour paints', katasol in chapter 24 has a precise meaning and is referring to the colorant obtained from the fruits of Chrozophora tinctoria. This plant is common in the Iberian Peninsula, and the use of the word grain, 'graos' ('panos o çumo de katasol e dos rgaos') could indicate the use of these fruits. This has similitudes with other medieval sources that mention this colorant which, independently of the name given, turnesol, morella, folium, or others, will be applied as a watercolour. In Liber diversarum arcium, one can find in chapter $\mathbb{\$} 1.13 .1 \mathrm{~A}$, the reference to an herb with 'three grain sprout in the seeds-and from these seeds specially are cloths dyed' [21]. In Chrozophora tinctoria, each fruit has three seeds, and it is in the shell of the fruit that the colorant is found, Fig. 3. If the final colour that will be obtained is blue or purple is still a matter of debate.

Interestingly, De Arte Illuminandi includes a very detailed recipe for preparing a blue colour folium that may be kept for a year, but afterwards turns into purple [22]. De Arte Iluminandi mentions that the colour should be prepared protected from the sun and the resulting clothlet should be kept inside books, in a dry place, while

\footnotetext{
2 "turnesole, tornesole, tournesole, tursole.

$n$. any colour of direct dye extracted from a flower or berry that is stored by being absorbed into a clothlet, to be subsequently released by immersion in a medium for e.g. an illuminator's colour, typically purple or blue (not a botanical name, i.e., not refering to the turnsole plants Chrozophora tinctoria (Juss.) or Helotropium spp., although the former plant itself may be used as the colour source)", in Clarke, p 441.
}

the 'book of all colour paints' refers that once the cloths are coloured with the vapours of the urine, they should be placed in the sun, until they reach a "blackberry" colour. Then, the clothlets should be kept away from "winter air' until they need to be used («e depois ke foren koradas do bafo dos vidos poyn-os ao sol ata ke tomen kolor komo morado e os panos enestas kolor e been en`sutos e korados guarda-os been do ar do inberno kuando ko.ele ki<seres aluminar o labrar...»).

Also, the 'book of all colour paints' gives instructions on how to temper it with gum arabic, advising to use it immediately to avoid colour loss.

\section{Conclusions}

From practitioner to practitioner the experimental edition of the book on how to make all the colour paints for illuminating books brings to the twenty first century laboratory, the science and the technology used to produce the colour paints for medieval illuminations. Ten years of systematic experimentation, now available in the Additional file 1 and summarized in Table 2, allowed us to conclude that the descriptions of the making of colours and paints are brief and precise, and in many cases, they include additional information on the most critical steps, which can be crucial to the practitioner. The present contribution highlights technical aspects relevant for the experimentation of this remarkable Portuguese Hebrew text, copied in the fifteenth century.

Our first contact with this book dates back to 2000, through the edition of Moreira de Sá, and experimentation in the laboratory started in 2001 with the first of a series 
Table 2 Colours and chapters in which instructions for their manufacture is described

\begin{tabular}{|c|c|c|c|c|}
\hline Colour and chapter & Chapter & Final product & Analytical techniques & References \\
\hline & 1,2 & Mosaic gold $\mathrm{SnS}_{2}$ & $\begin{array}{l}\text { XRD; XRF; Raman microscopy; FORS (VIS); } \\
\text { colorimetry }\end{array}$ & [24-31] \\
\hline & 10 & Red lead $\mathbf{P b}_{3} \mathrm{O}_{4}$ & $\begin{array}{l}\text { XRD; XRF; Raman microscopy; FORS (VIS); } \\
\text { colorimetry }\end{array}$ & {$[32-40]$} \\
\hline & 15 & Vermilion $\mathbf{H g S}$ & $\begin{array}{l}\text { XRD; XRF; Raman microscopy; FORS (VIS); } \\
\text { colorimetry }\end{array}$ & {$[31,41-50]$} \\
\hline & 11,12 & Verdigris $\mathrm{Cu}\left(\mathrm{CH}_{3} \mathrm{COO}\right)_{2} \cdot \mathrm{H}_{2} \mathrm{O}$ & $\begin{array}{l}\text { XRD; XRF; Raman microscopy; Infrared spec- } \\
\text { troscopy; FORS (VIS); colorimetry }\end{array}$ & {$[51-58]$} \\
\hline ess & 5 & Fine blue & & \\
\hline & 13 & Fine carmine lac dye red & $\begin{array}{l}\text { HPLC-DAD; microspectrofluorimetry; Raman } \\
\text { microscopy (SERS); infrared spectroscopy; } \\
\text { FORS (VIS); colorimetry }\end{array}$ & {$[5,38,59-70,75]$} \\
\hline & 8 & Rose brazilwood lake pigment & & {$[6,7,59,66,71-74]$} \\
\hline & 9 & Another rose colour brazilwood lake pigment & & \\
\hline & 27 & Good rose colour brazilwood lake pigment & & \\
\hline & 44 & Good rose colour brazilwood lake pigment & & \\
\hline In progress & 24 & Katasol & & \\
\hline In progress & 45 & Green lily & & {$[17,18]$} \\
\hline
\end{tabular}

Colour and colour paints were characterized with the main analytical techniques indicated. References that were important for the rationale of the recipe and publications dealing with the reconstructed pigments are also given. A particularly relevant publication is marked in bolditalics. Final products as described in "the book of all colour paints" are in italics

of unsuccessful experiments around vermilion production, $\mathrm{HgS}$, as it is described in chapter 15 . Which did not discourage us, since each single failure allowed to understand what had gone wrong, leading us closer to the experience in which, for the first time, we saw the 'ash' transformed into 'fire'. Despite the making of vermilion has been thoroughly investigated under Catarina Miguel's doctoral thesis [75], some aspects remain to be clarified, and the efficiency of the process continues to be as mysterious as when we began its experimentation $[23]^{3}$ is it missing a catalyst, obvious at the time, that we may have not yet

\footnotetext{
${ }^{3}$ Munir et al. [23] clearly demonstrated "that the transformation metacinnabar to cinnabar is exceedingly slow". By differential thermal analysis, they concluded that "the transformation of the red to black takes place with relative ease and is reproducible at temperature above the transformation temperature, but that the black to red transformation is exceedingly sluggish at temperatures below the transformation temperature, i.e., in the region where the red modification is stable".
}

discovered? We do not know, but in vermilion as in other colours, even in those that seem easy to reproduce, the research we share today is a work in progress.

We have made our best efforts to release it for the conference 'Manuscripts in the making: Art and Science' (December 2016), hoping this work may bring to discussion new perceptions and different angles, by others more knowledgeable, or with different know-how than ours, on the way we have interpreted these recipes.

\section{Additional file}

Additional file 1. Book of all colour paints.

\section{Authors' contributions}

MJM, RC, PN and TV contributed to the experiments and analysis of the data. All authors were involved in the interpretation of the results and in the 
editing and revising of the manuscript. All authors read and approved the final manuscript.

\section{Author details}

${ }^{1}$ Department of Conservation and Restoration and LAQV-REQUIMTE, Faculty of Sciences and Technology, NOVA University of Lisbon, 2829-516 Caparica, Portugal. ${ }^{2}$ Nello Carrara Institute of Applied Physics, National Research Council, 50019 Sesto Fiorentino, Italy.

\section{Acknowledgements}

These studies were supported by the Portuguese Science Foundation through three research projects and three Ph.D. grants, including the three awarded to Rita Castro, Paula Nabais and Tatiana Vitorino (Ph.D. Grant Nos. SFRH/BD/76789/2011, CORES Ph.D. programme PD/00253/2012: PD/ BD/105895/2014 and PD/BD/105902/2014), and through the scientific infrastructures funded through RECI/QEQ-MED/0330/2012, REM2013 and the Associated Laboratory for Sustainable Chemistry_Clean Processes and Technologies - LAQV, which is financed by national funds from FCT/MEC (UID/ QUI/50006/2015) and co-financed by the ERDF under the PT2020 Partnership Agreement (POCl-01-0145-FEDER-007265).

\section{Competing interests}

The authors declare that they have no competing interests.

\section{Publisher's Note}

Springer Nature remains neutral with regard to jurisdictional claims in published maps and institutional affiliations.

Received: 25 October 2017 Accepted: 5 July 2018

Published online: 27 July 2018

\section{References}

1. Melo MJ, Miranda A, Miguel C, Castro R, Lemos A, Muralha S, Lopes J, Gonçalves AP. The colour of medieval Portuguese illumination: an interdisciplinary approach. Rev Hist Arte. 2011;1:147-69. http://revistadehistor iadaarte.wordpress.com/. Accessed July 2018.

2. Melo MJ, Castro R, Miranda A. Colour in medieval portuguese manuscripts: between beauty and meaning. In: Sgamellotti A, Bunetti BG, Miliani $C$, editors. Science and art: the painted surface. Cambridge: RSC Publishing; 2014. p. 170-92.

3. Melo MJ, Miranda MA. Secrets et découvertes en couleur dans les manuscrits enluminés. In: Miranda MA, Miguélez Cavero A, editors. Portuguese studies on medieval illuminated manuscripts. Turnhout: Brepols; 2014. p. $1-30$

4. Melo MJ, Claro A. Bright light: microspectrofluorimetry for the characterization of lake pigments and dyes in works of art. Acc Chem Res. 2010;43(6):857-66.

5. Castro R, Pozzi F, Leona M, Melo MJ. Combining SERS and microspectrofluorimetry with historically accurate reconstructions for the characterization of lac dye paints in medieval manuscript illuminations. J Raman Spectrosc. 2014:45:1172-9.

6. Melo MJ, Otero V, Vitorino T, Araújo R, Muralha VSF, Lemos A, Picollo M. A spectroscopic study of brazilwood paints in medieval books of hours. App Spectrosc. 2014;68(4):434-44.

7. Melo MJ, Nabais P, Guimarães M, Araújo R, Castro R, Oliveira MC, Whitworth I. Organic dyes in illuminated manuscripts: an unique cultural and historic record. Phil Trans R Soc A. 2016:374(2082):1-20.

8. Melo MJ, Castro R. «O livro de como se fazem as cores»: medieval colours for practitioners. Online edition. 2016. https://www.dcr.fct.unl.pt/LivCo moFazemCores. Accessed July 2018.

9. Matos DM. The Ms. Parma 1959 in the context of portuguese hebrew illumination. Doctoral dissertation. Universidade de Lisboa Faculdade de Letras: Instituto de História da Arte; 2011

10. Afonso LU. New developments in the study of O Livro de como se fazem as cores das tintas. As Matérias da Imagem. Lisboa: Campo da Comunicação; 2010. p. 3-27.
11. Castro I. Notas sobre a língua do Livro de como se fazen as cores (ms. Parma 1959). As Matérias da Imagem. Lisboa: Campo da Comunicação; 2010. p. 87-96.

12. Blondheim DS. An old Portuguese work on manuscript illumination. Jew Q Rev. 1928;19(2):97-135.

13. Moreira de Sá A. O livro de como se fazem as cores, de Abraao B. Judah Ibn Hayim. Revista da Faculdade de Letras. 1960;4:210-23.

14. Strolovitch DL. O libro de komo se fazen as kores das tintas todas (Transliteration). As Matérias da Imagem. Lisboa: Campo da Comunicação; 2010. p. 213-36.

15. Villela-Petit I. Les Recettes pour l'enluminure. Do Livro judaico-português de como se fazem as cores. Medievalista Online. 2011:9. http://www2. fcsh.unl.pt/iem/medievalista/MEDIEVALISTA9/petit9005.html. Accessed 12 July 2018.

16. Larroche M. Le livre des couleurs, $\mathrm{O}$ livro de como se fazem as cores (1462). Toulouse: PUM; 2017.

17. Melo MJ. Missal blue: anthocyanins in nature and art. Dyes in history and archaeology, vol. 21. London: Archetype Publications; 2008. p. 65-74.

18. Melo MJ. History of natural dyes in the ancient mediterranean world. Handbook of Natural Colorants, Chichester: Wiley; 2009. p. 3-18 http:// media.wiley.com/product_data/excerpt/90/04705119/0470511990.pdf. Accessed July 2018

19. Coutinho I, Vilarigues M. The use of glass in medieval pigment making. In: Proceedings of the 5th GLASSAC International Conference. 2017:19-21.

20. Clarke $M$. The craft of lymmyng and the maner of steynyng: middle English recipes for painters, stainers, scribes, and illuminators. Oxford: Oxford University Press; 2016.

21. Clarke M. Mediaeval painters' materials and techniques: the Montpellier liber diversarum arcium. London: Archetype; 2011.

22. Brunello F. De arte illuminandi e altri trattati sulla tecnica della miniatura medievale. Vicenza: Neri Pozza Editore; 1992. p. 63-7.

23. Butler AR, Glidewell C, Pritchard SE, Needham J. Mosaic gold: studies of medieval European and Chinese recipes for the preparation of tin (IV) sulphide. Chem Br. 1983;19(2):132-5.

24. Xiao $\mathrm{H}$, Zhang $\mathrm{YC}$. In air synthesis of $\mathrm{SnS}_{2}$ nanoplates from tin, sulphur and ammonium chloride powders. Mater Chem Phys. 2008;112:742-4.

25. Xiao $\mathrm{H}$, Zhang $\mathrm{YC}$, Bai $\mathrm{H}$. Molten salt synthesis of $\mathrm{SnS}_{2}$ microplate particles. Mater Lett. 2009:63:809-11.

26. Zhang YC, Du ZN, Li SY, Zhang M. Novel synthesis and high visible light photocatalytic activity of $\mathrm{SnS}_{2}$ nanoflakes from $\mathrm{SnCl}_{2} \cdot 2 \mathrm{H}_{2} \mathrm{O}$ and $\mathrm{S}$ powders. App Catal B. 2010;95:159.

27. Nabais P, Castro R, Lopes GV, de Sousa LC, Melo MJ. Singing with light: an interdisciplinary study on the medieval Ajuda Songbook. J Mediev Iber Stud. 2016:8(2):283-312.

28. Munoz-Viñas S, Farrel EF. Estudio tecnico de los códices miniados renascentistas. Valencia: Biblioteca Histórica de la Universidad de Valencia; 1999.

29. Bicchieri M, Monti M, Piantanida G, Sodo A. Illuminations: secrets, alchemy and conservation in three case studies. Rev Hist Arte. 2011;1:174-81. http://revistadehistoriadaarte.wordpress.com/. Accessed July 2018.

30. Lehmann-Haupt H. The Göttingen Model Book. 2nd ed. Columbia: University of Missouri Press; 1978.

31. Munir ZA, Kashkooli IY, Street GB. Sublimation of IIB-VIA compounds. V. Relative thermal stability and heat of transformation of black mercury sulphide metacinnabar. High Temp Sci. 1973;5(1):8-15.

32. Verità M. Le vetrate artistiche: struttura, composizione, proprietà chimicofisiche dei vetri. In: Lefèvre RA, Pallot-Frossard I, editors. Le Materiau Vitreux: Verre et Vitraux. Bari: Edipuglia; 1998. p. 53-73.

33. Fitzhugh E. Red lead and minium. In: Feller RL, editor. Artist' pigments: a handbook of their history and characteristics, vol. 1. Washington: Oxford University Press; 1986. p. 109-40.

34. Buxbaum G. Industrial inorganic pigments. 2nd ed. Weinheim: Wiley-VCH; 1998

35. Cabral JMP. História breve dos pigmentos: das artes grega e romana. Boletim da Sociedade Portuguesa de Química. 2011:82:57-64.

36. Gettens RJ, Stout GL. Painting materials. London: Dover Publications; 1966.

37. Ciomartan DA, Clark RJH, McDonald LJ, Odlyha M. Studies on the thermal decomposition of basic lead (II) carbonate by Fourier-transform Raman 
spectroscopy, X-ray diffraction and thermal analysis. J Chem Soc Dalton Trans. 1996;18:3639-45.

38. Muralha VS, Miguel C, Melo MJ. Micro-Raman study of medieval cistercian 12th-13th century manuscripts: Santa Maria de Alcobaça, Portugal. J Raman Spectrosc. 2012:43(11):1737-46.

39. Miguel C, Claro A, Gonçalves AP, Muralha VSF, Melo MJ. A study on red lead degradation in the medieval manuscript, Lorvão Apocalypse (1189). J Raman Spectrosc. 2009;40:1966-73.

40. Melo MJ, Vilarigues M, Muralha VSF, Castro R. Fernão Vaz Dourado's colours. In: Miró M, editor. Universal Atlas of Fernão Vaz Dourado, 1571. Barcelona: M. Moleiro Editor; 2013. p. 168-86.

41. Miguel C, Pinto JV, Clarke M, Melo MJ. The alchemy of red mercury sulphide: the production of vermilion for medieval art. Dyes Pigments. 2014;102:210-7.

42. Dickson FW, Tunnel G. The stability relations of cinnabar and metacinnabar. Am Mineral. 1959:44:471-87.

43. Bell AMT, Pattrick RAD, Vaughan DJ. Structural evolution of aqueous mercury sulphide precipitates: energy-dispersive $\mathrm{X}$-ray diffraction studies. Mineral Mag. 2010;74:85-96.

44. Sharma RC, Chang YA. The Hg-S (Mercury-Sulfur) System. J Phase Equilibria. 1993;14:100-9.

45. Melo MJ, Miguel C. The making of vermilion in medieval Europe: historically accurate reconstructions from The book on how to make colours. In: Kroustallis S, Del Egido M, editors. Fatto D'Archimia: history and identification of artificial pigments. Madrid: IPCE; 2010

46. Charnock JM, Moyes LN, Pattrick RAD, Mosselmans JFW, Vaughan DJ, Livens FR. The structural evolution of mercury sulfide precipitate: an XAS and XRD study. Am Mineral. 2003;88:1197-203.

47. Potter RW, Barnes HL. Phase relations in the binary Hg-S. Am Mineral. 1978;63:1143-52.

48. Rodic D, Spasojevic V, Bajorek A, Onnerud P. Similarity of structure properties of $\mathrm{Hg} 1-\mathrm{xMn \times S}$ and $\mathrm{Cd1}-\mathrm{xMn \times S}$ (structure properties of $\mathrm{Hg}-\mathrm{MnS}$ and Cd-MnS). J Magn Magn Mater. 1996;152:159-64.

49. Gettens R, Chase M, Feller RL. Vermillion and cinnabar. Stud Conserv. 1972;17(2):45-69.

50. Rinse J. The vapour pressure, dissociation, and transition point of mercury sulphide. Recl Trav Chim Pays-Bas. 1928;47:28-32.

51. Scott DA. Copper and bronze in art: corrosion, colorants, conservation. Los Angeles: The Getty Conservation Institute; 2002.

52. Miguel C, Claro A, Lopes JA, Melo MJ. Copper pigments in medieval Portuguese illuminations: green, blue, greenish blue or bluish green? In: Hermens E, Townsend JH, editors. Sources and serendipity: testimonies of artists' practice. London: Archetype Publications; 2009. p. 33-8.

53. Andrés MS, Sancho N, Santos S, de la Roja JM. Verdigrís. Terminologia y recetas de preparación. In: del Egido M, Kroustallis S, editors. Fatto d'Archimia: Los pigmentos artificiales en las técnicas pictóricas. Madrid: Ministerio de Educación, Cultura y Deporte; 2012. p. 197-234.

54. Andrés MS, de la Roja JM, Santos S, Sancho N. Patrones de identificación del verdigrís: elaboración a partir de la reproducción de recetas antíguas. In: del Egido M, Kroustallis S, editors. Fatto d'Archimia: Los pigmentos artificiales en las técnicas pictóricas. Madrid: Ministerio de Educación, Cultura y Deporte; 2012. p. 237-60.

55. Chaplin TD, Clark RJH, Scott DA. Study by Raman microscopy of nine variants of green-blue pigment verdigris. J Raman Spectrosc. 2006;37:223-9.

56. Bernal MP, Albuquerque JA, Moral R. Composting of animal manures and chemical criteria for compost maturity assessment: a review. Bioresour Technol. 2009:100:5444-53.

57. Gilbert B, Denoël S, Weber G, Allart D. Analysis of green copper pigments in illuminated manuscripts by micro-Raman spectroscopy. Analyst. 2003;128:1213-7.

58. Ricciardi P, Pallipurath A, Rose K. It's not easy being green: a spectroscopic study of green pigments used in illuminated manuscripts. Anal Methods. 2013;5:3819-24.
59. Cardon D. Natural dyes: sources, tradition, technology and science. London: Archetype Publications; 2007.

60. Bose PK, Sankaranaraynan Y, Sen Gupta SC. Chemistry of lac. Ranchi: Indian Lac Research Institute; 1963.

61. Kirby J. Some aspects of medieval and renaissance lake pigment technology. In: Kirby J, editor. Dyes in history and archaeology, vol. 21. London: Archetype Publications; 2008. p. 89-108.

62. Colombini MP, Bonaduce I, Gautier G. Molecular pattern recognition of fresh and aged shellac. Chromatographia. 2003:58:357-64.

63. Wang L, Ishida Y, Ohtani H, Tsuge S. Characterisation of natural resin shellac by reactive pyrolysis gas chromatography in the presence of organic alkali. Anal Chem. 1999;71:1316-22.

64. Chairat M, Rattanaphani V, Bremner JB, Rattanaphani S, Perkins DF. An absorption spectroscopic investigation of the interaction of lac dyes with metal ions. Dyes Pigments. 2004;63(2):141-50.

65. Cañamares MV, Leona M. Surface-enhanced Raman scattering study of the red dye laccaic acid. J Raman Spectrosc. 2007;38:1259-66.

66. KarakT, Bhattacharyya P. Human urine as a source of alternative natural fertilizer in agriculture: a flight of fancy or an achievable reality. Resour Conserv Recycl. 2011:55:400-8.

67. Zhingang L, Zhao Q, Wang K, Lee D, Qiu W, Wang J. Urea hydrolysis and recovery of nitrogen and phosphorous as MAP from stale human urine. J Environ Sci. 2008;20:1018-24

68. Castro R, Miranda A, Melo MJ. Interpreting lac dye in medieval written sources: new knowledge from the reconstruction of recipes relating to illuminations in Portuguese manuscripts. In: Eyb-Green S, Townsend JH, Atkinson JK, Kroustallis S, Pilz K, van Leeuwen I, editors. Sources on art technology: back to basics. London: Archetype Publications; 2016. p. 88-99.

69. MOLAB. MOLAB report. 2009. http://www.eu-artech.org/files/MEDMA N-UserReport.pdf. Retrieved Nov 2016

70. Castro R. The book of birds in Portuguese scriptoria: preservation and access. Doctoral dissertation Universidade NOVA de Lisboa, Faculdade de Ciências e Tecnologia; 2012.

71. Vitorino T. A closer look at Brazilwood and its lake pigments. Master dissertation Universidade NOVA de Lisboa, Faculdade de Ciências e Tecnologia; 2012

72. Vitorino T, Melo MJ, Carlyle L, Otero V. New insights into brazilwood lake pigments manufacture through the use of historically accurate reconstructions. Stud Conserv. 2016;61(5):255-73.

73. Perkin A, Everest A. The natural organic colouring matters. London: Longmans, Green \& Company; 1918.

74. Berger S, Sicker D. Dyestuffs and coloured compounds. In: Berger S, Sicker $D$, editors. Classics in spectroscopy: isolation and structure elucidation of natural products. Weinheim: Wiley-VCH; 2009. p. 211-30.

75. Miguel C. Le Vert et le rouge: a study on the materials, techniques and meaning of the green and red colours in medieval Portuguese illuminations. Doctoral dissertation Universidade NOVA de Lisboa, Faculdade de Ciências e Tecnologia; 2012.

\section{Submit your manuscript to a SpringerOpen ${ }^{\circ}$ journal and benefit from:}

- Convenient online submission

- Rigorous peer review

- Open access: articles freely available online

- High visibility within the field

- Retaining the copyright to your article

Submit your next manuscript at $\boldsymbol{\nabla}$ springeropen.com 